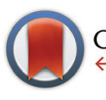

CrossMark $\leftarrow$ click for updates

Cite this: Dalton Trans., 2015, 44 20523

Received 7th August 2015,

Accepted 26th October 2015

DOI: $10.1039 / c 5 d t 03037 d$

www.rsc.org/dalton

\title{
Organometallic rhodium(III) and iridium(III) cyclopentadienyl complexes with curcumin and bisdemethoxycurcumin co-ligands $\uparrow$
}

\author{
Riccardo Pettinari, ${ }^{a}$ Fabio Marchetti, ${ }^{b}$ Claudio Pettinari, ${ }^{a}$ Francesca Condello, ${ }^{a}$ \\ Agnese Petrini, ${ }^{a}$ Rosario Scopelliti, ${ }^{c}$ Tina Riedel ${ }^{\mathrm{c}}$ and Paul J. Dyson ${ }^{\mathrm{c}}$
}

\begin{abstract}
A series of half-sandwich cyclopentadienyl rhodium(III) and iridium(III) complexes of the type [Cp*M(curc/ bdcurc) $\mathrm{Cl}]$ and $\left[\mathrm{Cp} * \mathrm{M}\right.$ (curc/bdcurc)(PTA)] $\left[\mathrm{SO}_{3} \mathrm{CF}_{3}\right]$, in which $\mathrm{Cp}^{*}=$ pentamethylcyclopentadienyl, curcH = curcumin and bdcurcH = bisdemethoxycurcumin as $\mathrm{O}^{\wedge} \mathrm{O}$-chelating ligands, and PTA = 1,3,5-triaza-7phosphaadamantane, is described. The $\mathrm{X}$-ray crystal structures of three of the complexes, i.e. [Cp*Rh-

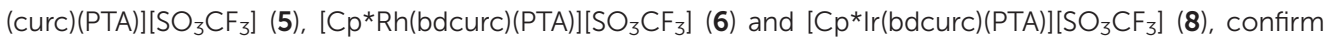
the expected "piano-stool" geometry. With the exception of $\mathbf{5}$, the complexes are stable under pseudophysiological conditions and are moderately cytotoxic to human ovarian carcinoma (A2780 and A2780cisR) cells and also to non-tumorigenic human embryonic kidney (HEK293) cells, but lack the cancer cell selectivity observed for related arene ruthenium(॥) complexes.
\end{abstract}

\section{Introduction}

Curcumin is a naturally occurring polyphenol derived from the rhizomes of turmeric (Curcuma longa). ${ }^{1}$ Curcumin (curcH) is the major component of three curcuminoids that give turmeric its characteristic yellow color. The minor curcuminoid components are demethoxycurcumin (dcurcH) and bisdemethoxycurcumin (bdcurcH) in which one or both -OMe functionalities at the outer phenol rings are removed.

Curcumin displays potent activity in vitro and in animal studies, acting as an anti-proliferative, anti-metastatic and antiangiogenic agent. ${ }^{2-5}$ Numerous studies have also explored the antioxidant, anti-hepatotoxic, anti-hyperlipidemic, antiviral, and anti-Alzheimer's disease effects. ${ }^{6,7}$ Despite the promising biological effects of curcumin at the preclinical and clinical levels its therapeutic applications are, however, restricted by poor solubility and rapid metabolism resulting in very low bioavailability following oral administration. ${ }^{8}$ One strategy used to improve the biological (drug-like) properties of

\footnotetext{
${ }^{a}$ School of Pharmacy, University of Camerino, via S. Agostino 1, 62032 Camerino MC, Italy.E-mail: riccardo.pettinari@unicam.it; Tel: +39-0737-632338

${ }^{b}$ School of Science and Technology, University of Camerino, via S. Agostino 1, 62032 Camerino MC, Italy

${ }^{c}$ Institute of Chemical Sciences and Engineering, Swiss Federal Institute of Technology (EPFL), CH-1015 Lausanne, Switzerland. E-mail: paul.dyson@epfl.ch; Fax: +41-21-6939885; Tel: +41-21-6939854

$\dagger$ Electronic supplementary information (ESI) available. CCDC 1412115-1412117. For ESI and crystallographic data in CIF or other electronic format see DOI: $10.1039 / \mathrm{c} 5 \mathrm{dt} 03037 \mathrm{~d}$
}

curcumin, which avoids covalently modifying the compound, ${ }^{9,10}$ is to coordinate it to metal complexes. ${ }^{11-13}$

Ruthenium compounds have emerged, in recent years, as promising alternatives to platinum drugs by displaying specific activities against different cancers and favourable toxicity and clearance properties. ${ }^{14-21}$ Previously, we have demonstrated that half-sandwich ruthenium-arene complexes with curcumin and bisdemethoxycurcumin and an ancillary chloride ligand show promising activity as anticancer agents. ${ }^{22,23}$ We have also shown that the replacement of chloride with the 1,3,5-triaza-7phosphaadamantane ligand (PTA) led to the formation of RAPTA-type complexes with superior solubility properties and also superior cytotoxicities. ${ }^{24}$ It was found that the presence or absence of peripheral methoxy groups in curcumin and the different arene rings do not strongly influence the biological activity whereas the PTA ligand appears to significantly improve the pharmacological properties of the curcuminmodified arene ruthenium(II) complexes.

Rhodium and iridium complexes have been explored for their anticancer properties with initial efforts being focused on $\operatorname{Rh}(\mathrm{I})$ and $\operatorname{Ir}(\mathrm{I})$ compounds with a square-planar geometry similar to that of cisplatin. ${ }^{25,26}$ Recently, more stable cyclopentadienyl $\mathrm{Rh}$ (III) and Ir(III) complexes, with higher structural diversity and a higher coordination number (6 versus 4$),{ }^{27,28}$ have been shown to have highly potent anticancer activity. ${ }^{29-40}$

Based on the highly promising pharmacological properties of the arene ruthenium(II) complexes incorporating curcumin and bisdemethoxycurcumin co-ligands, combined with the exciting developments on the anticancer properties of $\mathrm{Rh}$ (III) 
and Ir(III) organometallic compounds, we decided to integrate these two areas and prepare and evaluate some pentamethylcyclopentadienyl $\mathrm{Rh}$ (III) and Ir(III) compounds containing curcumin-based ligands and, in some cases, PTA. It should be noted that two curcumin complexes of $\mathrm{Rh}$ (III) and $\operatorname{Ir}(\mathrm{III})$ have been reported, ${ }^{41}$ but structural data and biological studies were not described.

\section{Results and discussion}

\section{Synthesis}

The rhodium(III) and iridium(III) pentamethylcyclopentadienyl complexes (1-4) were prepared in high yield (78-93\%) from the reaction of the appropriate dimer, $\left[\mathrm{Cp}^{*} \mathrm{MCl}_{2}\right]_{2},(\mathrm{M}=\mathrm{Rh}$ or $\mathrm{Ir}, \mathrm{Cp}^{*}=\eta^{5}$-pentamethylcyclopentadienyl) with the appropriate pro-ligand and $\mathrm{KOH}$ in methanol (Scheme 1). Analytical and spectral data for $\mathbf{1}$ and $\mathbf{3}$ are in accordance with literature data. $^{41}$

Complexes 1-4 are air stable and soluble in acetone, acetonitrile and DMSO and slightly soluble in alcohols. In addition, the curcumin complexes, $\mathbf{1}$ and $\mathbf{3}$, are also soluble in chlorinated solvents. Such different solubilities appear to be due to the different R' substituents of curcumin ligands (Scheme 1). The IR spectra of 1-4 show the typical $\nu(\mathrm{C}=\mathrm{O}, \mathrm{C}=\mathrm{C})$ bands of curc and bdcurc at lower wavenumbers than the corresponding bands in the free ligands as a consequence of coordination through both the carbonyl arms to the metal. In the far-IR region, several absorptions were observed in the range 482-445 and 252-242 $\mathrm{cm}^{-1}$. These may be assigned to $\nu(\mathrm{M}-\mathrm{O})$ and $\nu(\mathrm{M}-\mathrm{Cl})$ stretches, respectively. ${ }^{42}$

The NMR spectra of 1-4 corroborate the expected structures containing the bidentate curcumin and bisdemethoxycurcumin ligands. For example, a doublet is observed in the ${ }^{13} \mathrm{C}\left\{{ }^{1} \mathrm{H}\right\}^{43}$ NMR spectra of the rhodium derivatives $\mathbf{1}$ and 2 around $\delta 95\left(J\left({ }^{103} \mathrm{Rh}-{ }^{13} \mathrm{C}\right) \approx 6.9 \mathrm{~Hz}\right)$, whereas in the spectra of iridium derivatives 3 and $\mathbf{4}$ a singlet is observed. The electrospray ionisation (ESI) mass spectra of 1-4 display peaks corresponding to the species $\left[\mathrm{Cp}^{*} \mathrm{M}(\text { curc/bdcurc })\right]^{+}$, in which the chloride ligand has dissociated.
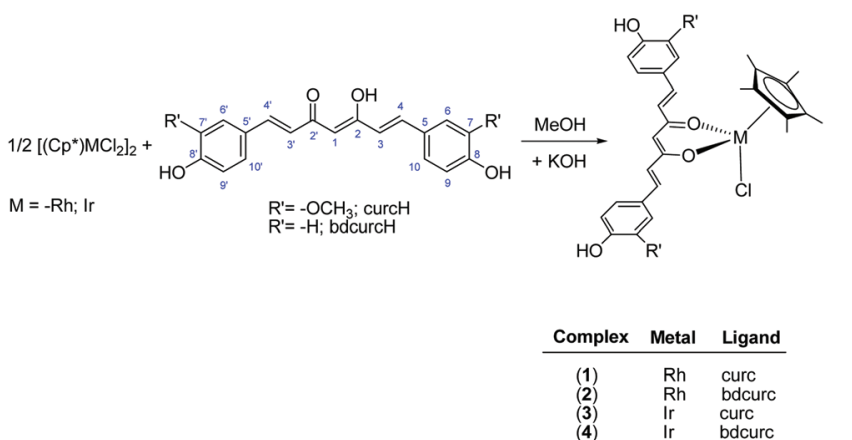

Scheme 1 Synthesis of 1-4.

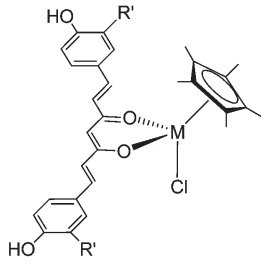

$\mathrm{R}^{\prime}=-\mathrm{OCH}_{3} ;$ curc
$\mathrm{R}^{\prime}=-\mathrm{H} ;$ bdcurc

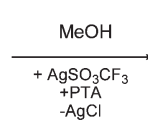

$+\mathrm{PTA}$
$-\mathrm{AgCl}$

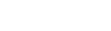

Scheme 2 Synthesis of 5-8.

The chloride ligand in 1-4 is readily replaced by the watersoluble phosphine 1,3,5-triaza-7-phosphaadamantane (PTA), by treatment of the complexes with $\mathrm{AgSO}_{3} \mathrm{CF}_{3}$ in methanol containing PTA, affording $\left[\mathrm{Cp}^{*} \mathrm{M}\right.$ (curc/bdcurc)(PTA)][ $\left.\mathrm{SO}_{3} \mathrm{CF}_{3}\right]$ ( $\mathrm{M}=\mathrm{Rh} 5$ and $\mathbf{6}$ and $\mathrm{M}=\mathrm{Ir} 7$ and 8), as depicted in Scheme 2 . The substitution of the chloride ligand by PTA and the formation of an ionic compound were confirmed by the disappearance of the $\nu(\mathrm{M}-\mathrm{Cl})$ band in the IR spectra of 5-8. Moreover, a characteristic absorption pattern in the region 1000-1200 $\mathrm{cm}^{-1}$, indicative of a non-coordinated $\mathrm{O}_{3} \mathrm{SCF}_{3}{ }^{-}$ anion, has also been observed. ${ }^{44}$ The ${ }^{1} \mathrm{H}$ NMR spectra of 5-8 in $\mathrm{CD}_{3} \mathrm{CN}$ display the expected signals due to the coordinated $\mathrm{Cp}^{*}$, curc or bdcurc and PTA ligands. The resonances due to the PTA are observed at a lower field with respect to those of uncoordinated PTA, thus confirming coordination to the metal center. $^{45}$

The ${ }^{31} \mathrm{P}$ NMR spectra of rhodium complexes 5 and 6 in $\mathrm{CD}_{3} \mathrm{CN}$ display a doublet centered at ca. $-34 \mathrm{ppm}$ with a ${ }^{1} J_{\mathrm{P}-\mathrm{Rh}}$ value of $c a$. $151 \mathrm{~Hz}$, and the iridium derivatives 7 and $8 \mathrm{com}$ prise a single resonance at $-56 \mathrm{ppm}$, in a range typical of related compounds. ${ }^{46,47}$

The ESI mass spectra of 5-8 in acetonitrile show two main peak envelopes, that of highest relative intensity corresponding to the fragment $\left[\mathrm{Cp}^{*} \mathrm{M}(\text { curc/bdcurc })\right]^{+}$, upon dissociation of PTA, the other corresponding to the intact species $\left[\mathrm{Cp}^{*} \mathrm{M}\right.$ (curc/ bdcurc)(PTA) $]^{+}$.

Complex 5 in water-DMSO (80-20\%) solution is stable, its ${ }^{31} \mathrm{P}$ NMR spectra remaining unchanged after $96 \mathrm{~h}$. The stability of 5 was also determined under pseudo-pharmacological conditions in $5 \mathrm{mM} \mathrm{NaCl}$ solution (being a model for the low intracellular chloride concentration in cells) and in $100 \mathrm{mM}$ $\mathrm{NaCl}$ solution (approximating to the higher chloride levels in blood). Solutions of the complexes $(c=2.0 \mathrm{mM})$ in aqueous $\mathrm{NaCl}\left(c=5 \mathrm{mM}\right.$ or $100 \mathrm{mM}$ in $\mathrm{D}_{2} \mathrm{O}$ containing $20 \%$ of $\left[\mathrm{D}_{6}\right]$ DMSO) were prepared and maintained at $37^{\circ} \mathrm{C}$ for 7 days. The decomposition of the complexes was monitored by ${ }^{1} \mathrm{H}$ and ${ }^{31} \mathrm{P}$ NMR spectroscopy.

The ${ }^{31} \mathrm{P}\left\{{ }^{1} \mathrm{H}\right\}$ spectrum of 5 displays a doublet at $-36.0 \mathrm{ppm}$ $\left(J_{\mathrm{PRh}}=155 \mathrm{~Hz}\right)$, corresponding to the starting species, $\left[\mathrm{Cp}^{*} \mathrm{Rh}-\right.$ (curc)(PTA) $]^{+}$(RhA) (Scheme 3 and Fig. 1). 


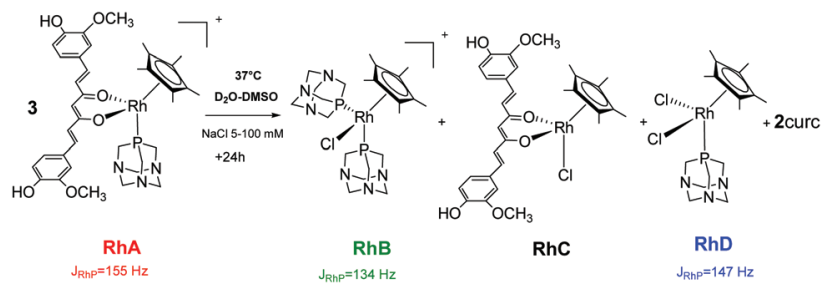

Scheme 3 Decomposition of 5 (RhA) into $\left[\mathrm{Cp} * \mathrm{Rh}(\mathrm{PTA})_{2} \mathrm{Cl}\right]^{+}(\mathrm{RhB})$, [Cp*Rh(curc)Cl] (RhC), [Cp*Rh(PTA)Cl $\left.{ }_{2}\right](\mathrm{RhD})$ and into curc, under pseudo-pharmacological conditions.

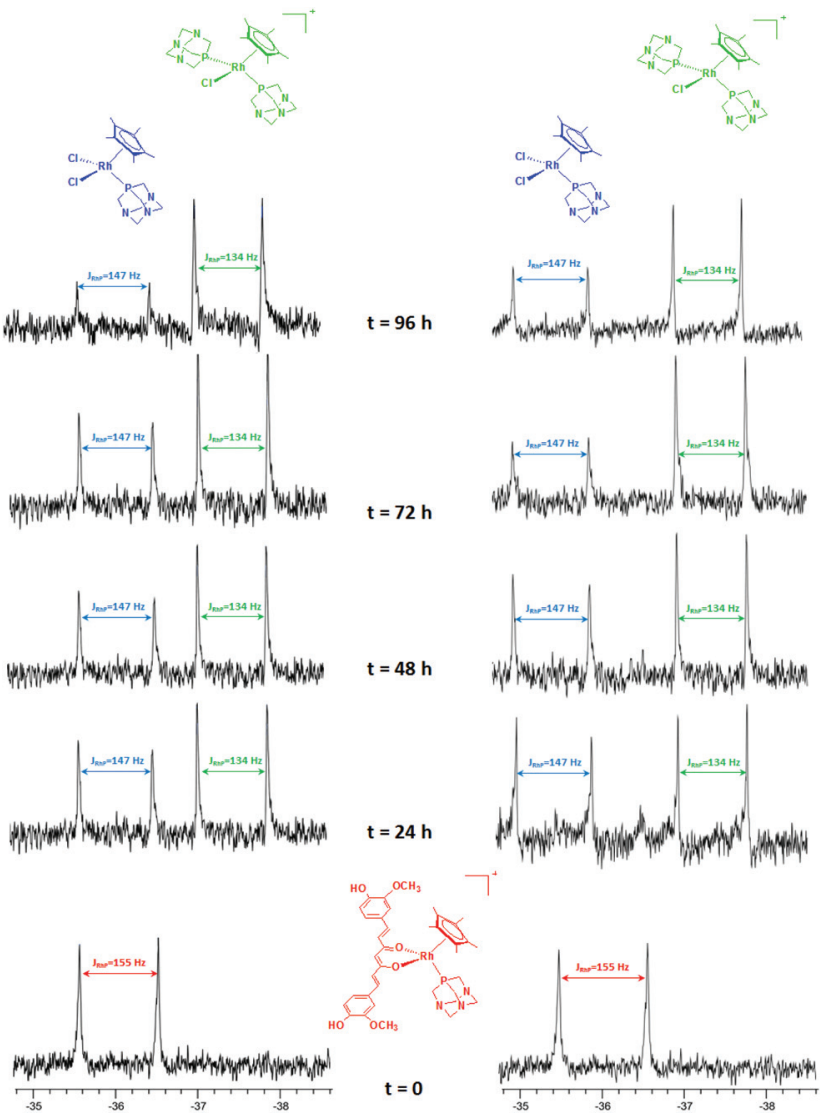

Fig. $1{ }^{31} \mathrm{P}$ NMR spectra of 5 in $5 \mathrm{mM}$ (left) and in $100 \mathrm{mM}$ (right) aqueous $\mathrm{NaCl}$ solution.

After 1 day, signals indicative of two new species are observed in both 5 and $100 \mathrm{mM}$ aqueous $\mathrm{NaCl}$ solutions. The first doublet in the range $-35.7 /-36.0 \mathrm{ppm}\left(J_{\mathrm{PRh}}=147 \mathrm{~Hz}\right)$ corresponds to the $\left[\mathrm{Cp}^{*} \mathrm{Rh}(\mathrm{PTA})_{2} \mathrm{Cl}\right]^{+}(\mathbf{R h B})$ species, previously reported by Macchioni and co-workers, ${ }^{48}$ arising from the release of the curc ligand and its replacement with a chloride and a second PTA from another $\left[\mathrm{Cp}^{*} \mathrm{Rh}(\text { curc })(\mathrm{PTA})\right]^{+}$species, which in turn likely affords a third neutral species of the formula [Cp* Rh(curc)Cl] (RhC). The second doublet in the range $-37.3 /-37.4 \mathrm{ppm}\left(J_{\mathrm{PRh}}=134 \mathrm{~Hz}\right)$ corresponds to the $\left[\mathrm{Cp}^{*} \mathrm{Rh}(\mathrm{PTA}) \mathrm{Cl}_{2}\right](\mathbf{R h D})$ species. $^{48}$

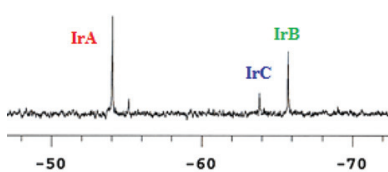

(a)

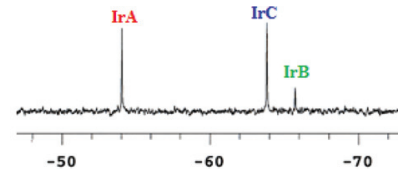

(b)
Fig. 2 (a) ${ }^{31} \mathrm{P}$ NMR chemical shifts for 7 in $\mathrm{D}_{2} \mathrm{O}-\mathrm{DMSO}$ and (b) after addition of excess $\mathrm{NaCl}$.

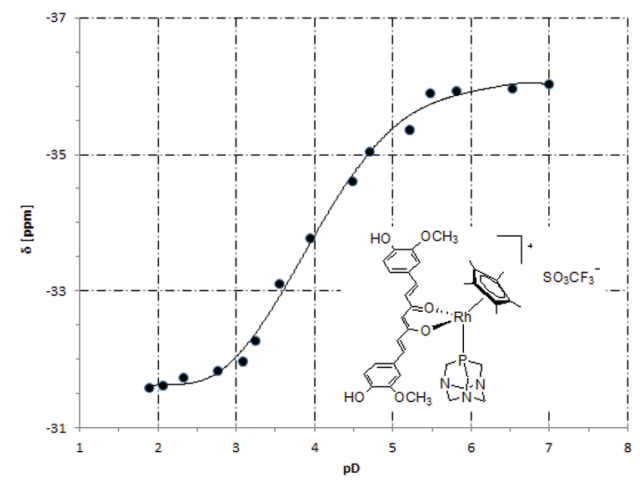

Fig. 3 A plot of the ${ }^{31} \mathrm{P}$ NMR chemical shift $(\delta)$ versus $\mathrm{pD}$ for 5 .

After $96 \mathrm{~h}$ an excess of PTA was added and, immediately, the resonance of $\left[\mathrm{Cp}^{*} \mathrm{Rh}(\mathrm{PTA}) \mathrm{Cl}_{2}\right] \quad(\mathbf{R h D})$ disappeared. Whereas, the intensity of $\left[\mathrm{Cp}^{*} \mathrm{Rh}(\mathrm{PTA})_{2} \mathrm{Cl}\right]^{+}(\mathbf{R h B})$ increased and the resonances of $\left[\mathrm{Cp}^{*} \mathrm{Rh}(\text { curc })(\mathrm{PTA})\right]^{+}(\mathrm{Rh} \mathbf{A})$ reappeared, together with a new signal due to $\left[\mathrm{Cp}^{*} \mathrm{Rh}(\mathrm{PTA})_{3}\right]^{+2}\left(J_{\mathrm{PRh}}=\right.$ $120 \mathrm{~Hz})^{48}$

The ${ }^{31} \mathrm{P}$ NMR spectrum of the iridium compound 7 in water-DMSO (80-20\%) solution showed immediately the formation of the hydrolysis products $\left[\mathrm{Cp}^{*} \mathrm{IrCl}_{2}\right.$ (PTA)] (IrC: -63.8 ppm) and $\left[\mathrm{Cp}^{*} \operatorname{IrCl}\left(\mathrm{OD}_{2}\right)(\mathrm{PTA})\right]^{+}($IrB: $-65.7 \mathrm{ppm})$, in equilibrium with the starting species $\left[\mathrm{Cp}^{*} \operatorname{Ir}(\text { curc })(\mathrm{PTA})\right]^{+}$(IrA: $-54.0 \mathrm{ppm})$. The nature of $\left[\mathrm{Cp}^{*} \operatorname{IrCl}_{2}(\mathrm{PTA})\right]$ has been confirmed by adding an excess of $\mathrm{NaCl}$ (Fig. 2b), whereas the [Cp* IrCl$\left.\left(\mathrm{OD}_{2}\right)(\mathrm{PTA})\right]^{+}$species has been hypothesized on the basis of a previous work by Peruzzini. ${ }^{47}$

The difference in stability of iridium complexes with respect to rhodium analogues has been previously observed for complexes with other ligands such as poly(pyrazolyl)borates. ${ }^{49,50}$

The ${ }^{31} \mathrm{P}$ NMR spectra of 5 in $\mathrm{D}_{2} \mathrm{O}$ containing 20\% DMSO were recorded at different $\mathrm{pD}$ values to determine the $\mathrm{p} K_{\mathrm{a}}$ value of the coordinated PTA ligand. The chemical shift was plotted against pD (Fig. 3) and the curve fitted using the Henderson-Hasselbalch equation to give a $\mathrm{p} K_{\mathrm{a}}$ of $3.36 \pm 0.02(0.44$ is subtracted to account for the difference between the $\mathrm{pH}$ and pD). ${ }^{51}$

The solid-state structures of 5, $\mathbf{6}$ and $\mathbf{8}$ were established by X-ray crystallography (see the Experimental section). Their structures are shown in Fig. 4 and relevant bond distances and angles are given in the caption. The three metal complexes 

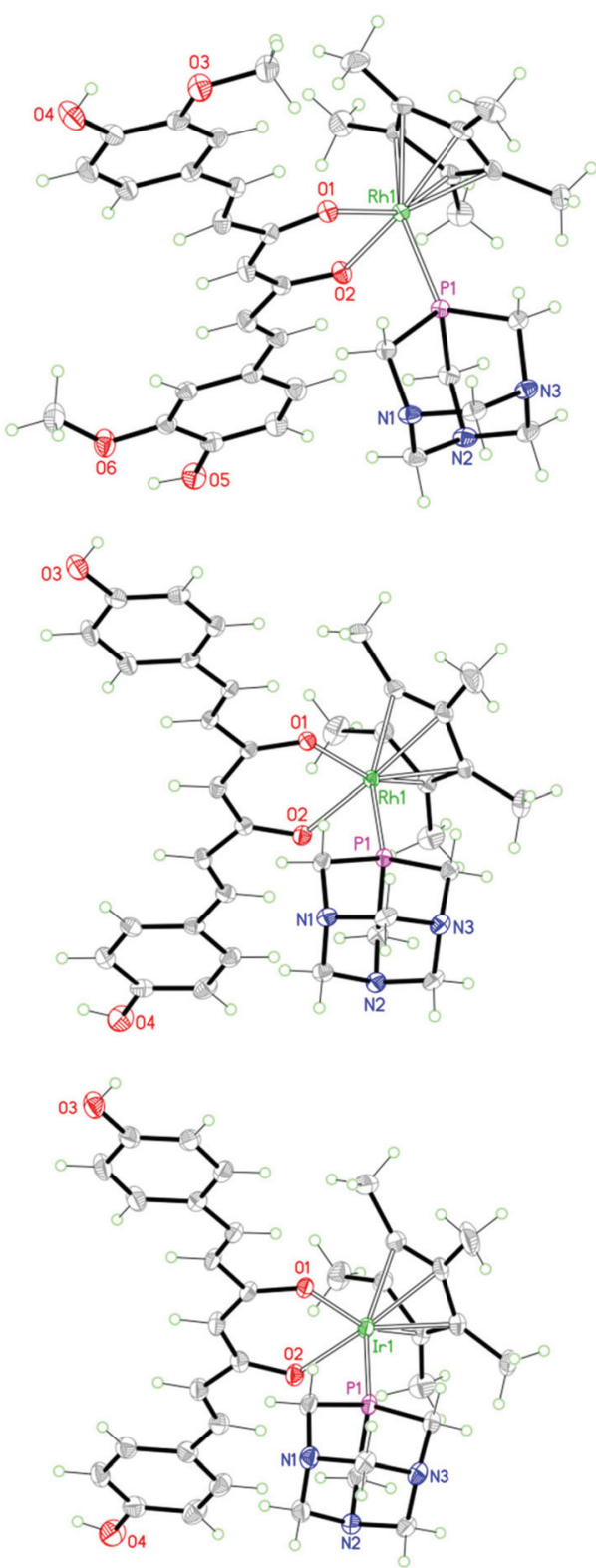

Fig. 4 Molecular structures of 5 (top), 6 (middle) and 8 (bottom). The counter-anion has been omitted for clarity. Bond distances $(\AA \AA)$ and angles ( ${ }^{\circ}$ ): [5] Rh1-O1, 2.107(1); Rh1-O2, 2.091(1); Rh1-P1, 2.314(1); Rh1$\eta^{5}$ (centroid), 1.802(1). [6] Rh1-O1, 2.109(2); Rh1-O2, 2.089(2); Rh1-P1, 2.313(1); Rh1- $\eta^{5}$ (centroid), 1.808(2). [8] Ir1-O1, 2.117(4); Ir1-O2, 2.101(4); Ir1-P1, 2.299(2), Ir1- $\eta^{5}$ (centroid), 1.810(3).

display the standard piano-stool geometry. Ligands show an almost planar geometry (the angles between the aromatic rings being $1.3^{\circ}, 4.6^{\circ}$ and $4.0^{\circ}$ for compounds 5,6 and 8 , respectively), with a small twist around the central backbone (the calculated dihedral angles for the $-\mathrm{C}=\mathrm{C}(=\mathrm{O})-\mathrm{C}=$ moieties varies from $1.7^{\circ}$ in 5 to $8^{\circ}$ in 8 to $8.8^{\circ}$ in 6 ). The bond distances and angles around the metal centers (see the caption to Fig. 4) fall in the range of values found in the literature for similar compounds. ${ }^{19}$ Strong intermolecular hydrogen bonds are observed between the ligands and the anions $\left(\mathrm{CF}_{3} \mathrm{SO}_{3}{ }^{-}\right)$
$\left[\mathrm{O} \cdots \mathrm{O}, 2.716(2) \AA,<\mathrm{OHO}, 156(3)^{\circ}\right.$ in 5; O $\cdots \mathrm{O}, 2.716(4) \AA$, $<\mathrm{OHO}, 167^{\circ}$ in 6; O $\cdots \mathrm{O}, 2.706(7) \AA,<\mathrm{OHO}, 167^{\circ}$ in 8] and between the ligands and the coordinated PTA of neighboring complexes $\left[\mathrm{O} \cdots \mathrm{N}, 2.810(2) \AA,<\mathrm{OHN}, 155(3)^{\circ}\right.$ in 5; $\mathrm{O} \cdots \mathrm{N}$, 2.760(4) $\AA$, < $<\mathrm{OHN}, 163^{\circ}$ in 6; O $\cdots \mathrm{N}, 2.744(7) \AA .<\mathrm{OHN}, 163^{\circ}$ in 8]. Additional intramolecular $\mathrm{OH} \cdots \mathrm{O}$ interactions are observed in the crystal of 5 .

The antiproliferative effects of 1-8 were investigated in two human ovarian cancer cell lines, A2780 and the cisplatin resistant A2780cisR cell line, as well as in non-tumorigenic human embryonic kidney (HEK293) cells. IC $_{50}$ values for compounds 1-8 were determined after a 72 hour exposure period using the MTT assay (Table 1 and the Experimental section).

Table 1 Cytotoxicity of 1-8 following incubation for $72 \mathrm{~h}$ on human ovarian carcinoma A2780 and A2780R (cisplatin-resistant) and nontumorigenic human embryonic kidney HEK293 cell lines

\begin{tabular}{lrrr}
\hline Compound & \multicolumn{1}{l}{$\begin{array}{l}\mathrm{A} 2780 \\
\left(\mathrm{IC}_{50}, \mu \mathrm{M}\right)\end{array}$} & \multicolumn{1}{c}{$\begin{array}{l}\mathrm{A} 2780 \mathrm{cisR} \\
\left(\mathrm{IC}_{50}, \mu \mathrm{M}\right)\end{array}$} & \multicolumn{1}{c}{$\begin{array}{l}\mathrm{HEK} 293 \\
\left(\mathrm{IC}_{50}, \mu \mathrm{M}\right)\end{array}$} \\
\hline curcH & $4.0 \pm 0.1$ & $3.2 \pm 0.2$ & $1.1 \pm 0.1$ \\
bdcurcH & $4.6 \pm 0.1$ & $4.6 \pm 0.2$ & $2.2 \pm 0.1$ \\
$\mathbf{1}$ & $14.9 \pm 2.1$ & $12.3 \pm 0.3$ & $13.7 \pm 0.3$ \\
$\mathbf{2}$ & $20.0 \pm 2.0$ & $18.1 \pm 0.2$ & $31.8 \pm 0.2$ \\
$\mathbf{3}$ & $23.2 \pm 0.8$ & $14.1 \pm 2.5$ & $16.3 \pm 0.7$ \\
$\mathbf{4}$ & $20.7 \pm 5.6$ & $23.6 \pm 2.3$ & $26.1 \pm 2.9$ \\
$\mathbf{5}$ & $12.5 \pm 0.5$ & $16.0 \pm 3.0$ & $17.2 \pm 4.8$ \\
$\mathbf{6}$ & $14.7 \pm 2.2$ & $17.7 \pm 0.2$ & $19.0 \pm 4.0$ \\
$\mathbf{7}$ & $23.2 \pm 2.3$ & $39.4 \pm 9.4$ & $29.4 \pm 3.9$ \\
$\mathbf{8}$ & $21.0 \pm 1.0$ & $33.3 \pm 3.6$ & $15.6 \pm 1.4$ \\
& & &
\end{tabular}

All the complexes were cytotoxic at moderate micromolar concentrations against both cancer cell lines with $\mathrm{IC}_{50}$ values in the $12-23 \mu \mathrm{M}$ range for $\mathrm{A} 2780$ cells and in the $12-40 \mu \mathrm{M}$ range for A2780cisR cells, indicating a lack of cross-resistance. In HEK293 cells comparable $\mathrm{IC}_{50}$ values were obtained (14-32 $\mu \mathrm{M})$ suggesting a lack of cancer cell selectivity.

Previously reported $\mathrm{Rh}$ (III) $\mathrm{Cp}^{*}$ complexes containing maltol or allomaltol as $\mathrm{O}^{\wedge} \mathrm{O}$-chelating ligands were all inactive toward A549, CH1 and SW480 cell lines, ${ }^{52}$ whereas the lapachol complex shows good activity and selectivity toward the CH1 ovarian carcinoma cell line. ${ }^{53}$ A cyclometalated rhodium(III) complex shows lower ${ }^{54}$ or comparable $\mathrm{IC}_{50}$ values toward A2780 cells. $^{39,55} \operatorname{Ir}(\mathrm{III}) \mathrm{Cp}^{*}$ complexes of the formula $\left[\left(\eta^{5}-\mathrm{Cp}^{*}\right) \mathrm{Ir}\right.$ $\left.\left(\mathrm{L}^{\wedge} \mathrm{L}^{\prime}\right) \mathrm{Cl}\right]^{0 /+}$ containing $\mathrm{N}^{\wedge} \mathrm{N}-($ phenanthroline, 2,2'-bipyridine, ethylenediamine) and $\mathrm{N}^{\wedge} \mathrm{O}-($ picolinate) chelating ligands, are inactive on $\mathrm{A} 2780$ cells with $\mathrm{IC}_{50}$ values $>100 \mu \mathrm{M},{ }^{31,33}$ even with modified $\mathrm{Cp}^{*}$-type ligands. ${ }^{31,56}$ However, varying the chelating ligand ${ }^{32,40,57-59}$ can lead to compounds with $\mathrm{IC}_{50}$ values considerably higher than cisplatin.

Cytotoxicity data for the A2780 cell line are comparable with the $\mathrm{IC}_{50}$ value obtained for $[(p$-cymene $) \mathrm{Ru}($ curc $) \mathrm{Cl}]$ in the HEK293 cell line, however, the rhodium(III) and iridium(III) complexes are 20-60 times less active than their corresponding ruthenium(II) analogues in the ovarian cancer cell lines.

The rhodium(III) and iridium(III) complexes with chloride 1-4 or PTA 5-8 co-ligands exhibit similar biological activities. 
This behaviour contrasts to that of the related ruthenium(II) complexes, in which the activity/selectivity of the PTA-containing complexes was superior to the chloride-based complexes. ${ }^{22}$ However, in keeping with the ruthenium(II) complexes, the nature of the curcuminoid ligand employed, i.e. curcumin and bisdemethoxycurcumin, plays little discernible role. It is not unreasonable to assume that following dissociation of the curcuminoid ligand the rhodium(III)/iridium(III) complexes interact with different biological targets compared to the arene ruthenium(II) derivatives, implying a different mechanism of action.

\section{Conclusions}

Compared to platinum- or ruthenium-based anticancer agents, the study of the medicinal properties of rhodium and iridium complexes is poorly developed. Here, we described a series of novel pentamethylcyclopentadienyl rhodium(III) and iridium(III) complexes with curcumin or bisdemethoxycurcumin coligands and a chloride or PTA ligand, these complexes being closely related to the previously studied arene ruthenium(II) complexes. ${ }^{24}$ Unlike related ruthenium(II) complexes with a PTA ligand, which display 100 times higher cytotoxicity towards cancer cells versus healthy cells, the compounds reported here are moderately cytotoxic to both human ovarian cancer cells and non-tumorigenic human embryonic kidney cells. Since it has been shown that all these compounds are able to release their curcuminoid ligands under physiologicallike conditions it would suggest that the differences in activity between the pentamethylcyclopentadienyl $\mathrm{M}$ (III) $(\mathrm{M}=\mathrm{Rh} / \mathrm{Ir})$ and arene ruthenium(II) compounds originate from the different metal fragments, which are known to have different binding preferences for certain biological targets. ${ }^{60}$

\section{Experimental section}

\section{General procedures}

The dimers $\left[\mathrm{Cp}^{*} \mathrm{MCl}_{2}\right]_{2}(\mathrm{M}=\mathrm{Rh}$ or $\mathrm{Ir})$ were purchased from Aldrich. Curcumin and bisdemethoxycurcumin were purchased from TCI Europe and were used as received. All other materials were obtained from commercial sources and were used as received. IR spectra were recorded from 4000 to $30 \mathrm{~cm}^{-1}$ on a Perkin-Elmer Frontier Spectrometer FT-IR/FIR instrument. ${ }^{1} \mathrm{H}$ and ${ }^{13} \mathrm{C}$ NMR spectra were recorded on a 400 Mercury Plus Varian instrument operating at room temperature (400 MHz for ${ }^{1} \mathrm{H}$ and $100 \mathrm{MHz}$ for ${ }^{13} \mathrm{C}$ ) relative to TMS. Positive and negative ion electrospray ionization mass spectra (ESI-MS) were obtained on a Series 1100 MSI detector HP spectrometer using methanol as the mobile phase. Solutions (3 $\mathrm{mg} \mathrm{mL}^{-1}$ ) for analysis were prepared using reagent-grade methanol. Masses and intensities were compared to those calculated using IsoPro Isotopic Abundance Simulator, version 2.1.28. Melting points are uncorrected and were recorded on a STMP3 Stuart scientific instrument and on a capillary apparatus. Samples for microanalysis were dried in vacuo to constant weight $\left(20^{\circ} \mathrm{C}, \mathrm{ca} .0 .1\right.$ Torr $)$ and analysed on a Fisons Instruments 1108 CHNS-O elemental analyzer.

\section{Synthesis of complexes 1-8}

[Cp*Rh(curc)Cl] (1). Curcumin (curc, $184.2 \mathrm{mg}, 0.5 \mathrm{mmol}$ ) was dissolved in methanol $(20 \mathrm{~mL})$ and $\mathrm{KOH}(28.05 \mathrm{mg}$, $0.5 \mathrm{mmol}$ ) was added. The mixture was stirred for $1 \mathrm{~h}$ at room temperature and then $\left[\mathrm{Cp}^{*} \mathrm{RhCl}_{2}\right]_{2}(154.52 \mathrm{mg}, 0.25 \mathrm{mmol})$ was added. The mixture was stirred for $24 \mathrm{~h}$ at room temperature and an orange precipitate formed which was filtered off and washed with $5 \mathrm{~mL}$ of diethyl ether $(278.82 \mathrm{mg}, 0.43 \mathrm{mmol}$, yield $87 \%$ ). The residue was concentrated to $c a .2 \mathrm{~mL}$ and stored at $4{ }^{\circ} \mathrm{C}$. Red crystals were slowly afforded within 2 days. 1 is soluble in acetone, acetonitrile, chlorinated solvents, DMSO and slightly soluble in alcohols. M.p. 264-265 ${ }^{\circ} \mathrm{C}$. Anal. Calcd for $\mathrm{C}_{31} \mathrm{H}_{34} \mathrm{ClO}_{6} \mathrm{Rh}$ : C, 58.09; H, 5.35. Found: C, 58.00; $\mathrm{H}, 5.26$. IR ( $\left.\mathrm{cm}^{-1}\right): 3563 \mathrm{w}, 3157 \mathrm{~m}, 1622 \mathrm{~m}, 1590 \mathrm{~m} \nu(\mathrm{C}=\mathrm{C})$, $1505 \mathrm{~s}, 472 \mathrm{~m}, 454 \mathrm{w}, 242 \mathrm{~s} \nu(\mathrm{Rh}-\mathrm{Cl}) .{ }^{1} \mathrm{H} \mathrm{NMR}\left(\mathrm{CDCl}_{3}, 293 \mathrm{~K}\right)$ : $\delta, 1.69\left(\mathrm{~s}, 15 \mathrm{H}, \mathrm{CH}_{3 \mathrm{Cp}^{*}}\right), 3.94\left(\mathrm{~s}, 6 \mathrm{H}, \mathrm{OCH}_{3}\right.$ of curc), $5.78(\mathrm{~s}, 1 \mathrm{H}$, $\mathrm{C}(1) \mathrm{H}$ of curc), 6.51 (d, $2 \mathrm{H}, \mathrm{C}\left(3,3^{\prime}\right) \mathrm{H}$ of curc, $\left.{ }^{3} J_{\text {trans }}=16 \mathrm{~Hz}\right)$, $6.90\left(\mathrm{~d}, 2 \mathrm{H}, \mathrm{C}\left(9,9^{\prime}\right) \mathrm{H}\right.$ of curc, $\left.{ }^{3} J_{\text {aromH-H }}=9 \mathrm{~Hz}\right), 7.05(\mathrm{~m}, 4 \mathrm{H}$, $\mathrm{C}\left(6,6^{\prime}\right) \mathrm{H}$ and $\mathrm{C}\left(10,10^{\prime}\right) \mathrm{H}$ of curc), 7.57 (d, 2H, C(4, 4') $\mathrm{H}$ of curc, $\left.{ }^{3} J_{\text {trans }}=16 \mathrm{~Hz}\right) \cdot{ }^{13} \mathrm{C} \mathrm{NMR}\left(\mathrm{CDCl}_{3}, 293 \mathrm{~K}\right): \delta, 8.8(\mathrm{~s}$, $\left.\mathrm{CH}_{3 \mathrm{Cp}^{*}}\right), 56.1$ (s, $\mathrm{OCH}_{3}$ of curc), $94.7\left(\mathrm{~d}, \mathrm{C}_{\mathrm{Cp}^{*}}, J\left({ }^{103} \mathrm{Rh}-{ }^{13} \mathrm{C}\right)=\right.$ $6.9 \mathrm{~Hz}$ ), 102.2 (s, C(1) of curc), 109.4 (s, C(6, 6') of curc), 114.8 (s, C(9, 9') of curc), 122.5 (s, C(10, 10') of curc), 126.7 (s, C(5, 5') of curc), 128.8 (s, C(3, 3') of curc), 138.4 (s, C(4, 4') of curc), 146.8 (s, C(7, 7') of curc), $147.2\left(\mathrm{~s}, \mathrm{C}\left(8,8^{\prime}\right)\right.$ of curc), 178.7 (s, $\mathrm{C}\left(2,2^{\prime}\right)=\mathrm{O}$ of curc). ESI-MS $(+) \mathrm{CH}_{3} \mathrm{OH}(\mathrm{m} / z$, relative intensity $\%): 605[100]\left[\mathrm{Cp}^{*} \mathrm{Rh}(\text { curc })\right]^{+}$.

[Cp*Rh(bdcurc)Cl] (2). Compound 2 was prepared following a procedure similar to that reported for $\mathbf{1}$ by using bdcurc (270.12 mg, $0.46 \mathrm{mmol}$, yield 93\%). 2 is soluble in acetone, acetonitrile, DMSO and slightly soluble in alcohols. M.p. 235-236 ${ }^{\circ} \mathrm{C}$. Anal. Calcd for $\mathrm{C}_{29} \mathrm{H}_{30} \mathrm{ClO}_{4} \mathrm{Rh}$ : C, 59.96; H, 5.21. Found: C, 59.84; H, 5.16. IR ( $\left.\mathrm{cm}^{-1}\right): 3165$ br, $1618 \mathrm{sh}, 1599 \mathrm{~m}$ $\nu(\mathrm{C}=\mathrm{C}), 1492 \mathrm{~s}, 478 \mathrm{~m}, 450 \mathrm{w}, 244 \mathrm{~s} \nu(\mathrm{Rh}-\mathrm{Cl}) .{ }^{1} \mathrm{H}$ NMR $\left(\mathrm{CD}_{3} \mathrm{CN}, 293 \mathrm{~K}\right): \delta, 1.63\left(\mathrm{~s}, 15 \mathrm{H}, \mathrm{CH}_{3 \mathrm{Cp}^{*}}\right), 5.94(\mathrm{~s}, 1 \mathrm{H}, \mathrm{C}(1) \mathrm{H}$ of bdcurc), $6.65\left(\mathrm{~d}, 2 \mathrm{H}, \mathrm{C}\left(3,3^{\prime}\right) \mathrm{H}\right.$ of bdcurc, $\left.{ }^{3} J_{\text {trans }}=16 \mathrm{~Hz}\right), 6.88$ $\left(\mathrm{m}, 4 \mathrm{H}, \mathrm{C}\left(7,7^{\prime}\right) \mathrm{H}\right.$ and $\mathrm{C}\left(9,9^{\prime}\right) \mathrm{H}$ of bdcurc), $7.46(\mathrm{~s}, 2 \mathrm{H}, \mathrm{OH}$ of bdcurc), 7.55 (m, 4H, C(6, $\left.6^{\prime}\right) \mathrm{H}$ and $\mathrm{C}\left(10,10^{\prime}\right) \mathrm{H}$ of bdcurc), 7.62 $\left(\mathrm{d}, 2 \mathrm{H}, \mathrm{C}\left(4,4^{\prime}\right) \mathrm{H}\right.$ of curc, $\left.{ }^{3} J_{\text {trans }}=16 \mathrm{~Hz}\right) \cdot{ }^{13} \mathrm{C} \mathrm{NMR}\left(\mathrm{CD}_{3} \mathrm{CN}\right.$, $293 \mathrm{~K}): \delta, 9.4\left(\mathrm{~s}, C \mathrm{H}_{3 \mathrm{Cp}}\right), 95.5\left(\mathrm{~d}, \mathrm{C}_{\mathrm{Cp}^{*}}, J\left({ }^{103} \mathrm{Rh}-{ }^{13} \mathrm{C}\right)=7.0 \mathrm{~Hz}\right)$, 102.3 (s, C(1) of bdcurc), 116.8 (s, C(7, 7') and $\mathrm{C}\left(9,9^{\prime}\right)$ of bdcurc), 122.4 (s, C(6, 6' and (s, C(10, 10') of bdcurc), 126.7 (s, $\mathrm{C}\left(5,5^{\prime}\right)$ of bdcurc), 131.2 (s, C(4, 4') of bdcurc), 141.1 (s, C(3, 3') of bdcurc), 146.8 (s, C(8, 8') of bdcurc), 178.7 (s, $\mathrm{C}\left(2,2^{\prime}\right)=\mathrm{O}$ of bdcurc). ESI-MS $(+) \mathrm{CH}_{3} \mathrm{CN}(\mathrm{m} / \mathrm{z}$, relative intensity \%): 545 $[100]\left[\mathrm{Cp}^{*} \mathrm{Rh}(\text { bdcurc })\right]^{+}$.

[CP* $\mathbf{I r}($ curc)Cl] (3). Compound 3 was prepared following a procedure similar to that reported for 1 by using $\left[\mathrm{Cp}^{*} \mathrm{IrCl}_{2}\right]_{2}$ (284.8 $\mathrm{mg}, 0.39 \mathrm{mmol}$, yield $78 \%$ ). 3 is soluble in acetone, acetonitrile, chlorinated solvents, DMSO and slightly soluble in alcohols. M.p. 210-212 ${ }^{\circ} \mathrm{C}$. Anal. Calcd for $\mathrm{C}_{31} \mathrm{H}_{34} \mathrm{ClO}_{6} \mathrm{Ir}$ : C, 50.99; H, 4.69. Found: C, 50.74; H, 4.62. IR ( $\left.\mathrm{cm}^{-1}\right): 3544 \mathrm{w}$, $3270 \mathrm{~m}, 1621 \mathrm{~m}, 1586 \mathrm{~m} \nu(\mathrm{C}=\mathrm{C}), 1504 \mathrm{~s}, 474 \mathrm{~m}, 461 \mathrm{w}, 245 \mathrm{~s}$ 
$\nu(\mathrm{Ir}-\mathrm{Cl}) .{ }^{1} \mathrm{H}$ NMR $\left(\mathrm{CDCl}_{3}, 293 \mathrm{~K}\right): \delta, 1.66\left(\mathrm{~s}, 15 \mathrm{H}, \mathrm{CH}_{3 \mathrm{Cp}^{*}}\right), 3.93$ (s, $6 \mathrm{H}, \mathrm{OCH}_{3}$ of curc), 5.50 (s, $1 \mathrm{H}, \mathrm{C}(1) \mathrm{H}$ of curc), 6.45 (d, $2 \mathrm{H}$, $\mathrm{C}\left(3,3^{\prime}\right) \mathrm{H}$ of curc, $\left.{ }^{3} \mathrm{~J}_{\text {trans }}=16 \mathrm{~Hz}\right), 6.89\left(\mathrm{~d}, 2 \mathrm{H}, \mathrm{C}\left(9,9^{\prime}\right) \mathrm{H}\right.$ of curc, $\left.{ }^{3} J_{\text {aromH-H }}=8 \mathrm{~Hz}\right), 7.05\left(\mathrm{~m}, 4 \mathrm{H}, \mathrm{C}\left(6,6^{\prime}\right) \mathrm{H}\right.$ and $\mathrm{C}\left(10,10^{\prime}\right) \mathrm{H}$ of curc), 7.55 (d, 2H, C(4, $\left.4^{\prime}\right) \mathrm{H}$ of curc, $\left.{ }^{3} J_{\text {trans }}=16 \mathrm{~Hz}\right) .{ }^{13} \mathrm{C} \mathrm{NMR}$ $\left(\mathrm{CDCl}_{3}, 293 \mathrm{~K}\right): \delta, 9.0\left(\mathrm{~s}, \mathrm{CH}_{3 \mathrm{Cp}^{*}}\right), 56.2\left(\mathrm{~s}, \mathrm{OCH}_{3}\right.$ of curc), 83.8 (s, $\left.C_{\mathrm{Cp}^{*}}\right), 103.3$ (s, C(1) of curc), 109.3 (s, C(6, 6') of curc), 114.9 (s, C(9, 9') of curc), 122.5 (s, C(10, 10') of curc), 126.3 (s, C(5, 5') of curc), 128.9 (s, C(3, 3') of curc), 138.3 (s, C(4, 4') of curc), 147.0 (s, C(7, 7') of curc), 147.2 (s, C(8, 8') of curc), 176.5 (s, $\mathrm{C}\left(2,2^{\prime}\right)=\mathrm{O}$ of curc). ESI-MS $(+) \mathrm{CH}_{3} \mathrm{OH}(\mathrm{m} / z$, relative intensity $\%): 695[100]\left[\mathrm{Cp}^{*} \operatorname{Ir}(\text { curc })\right]^{+}$.

[Cp* $\mathbf{I r}($ bdcurc)Cl] (4). Compound 4 was prepared following a procedure similar to that reported for 2 by using $\left[\mathrm{Cp}^{*} \mathrm{IrCl}_{2}\right]_{2}$ (298.25 mg, $0.44 \mathrm{mmol}$, yield 89\%). 4 is soluble in alcohols, acetone, acetonitrile, DMSO and slightly soluble in chlorinated solvents. M.p. 230-232 ${ }^{\circ} \mathrm{C}$. Anal. Calcd for $\mathrm{C}_{29} \mathrm{H}_{30} \mathrm{ClIrO}_{4}$ : C, 51.97; H, 4.51. Found: C, 51.84; H, 4.48. IR ( $\left.\mathrm{cm}^{-1}\right): 3214 \mathrm{w}$, $1621 \mathrm{sh}, 1598 \mathrm{~m} \nu(\mathrm{C}=\mathrm{C}), 1493 \mathrm{~s}, 1269 \mathrm{~s}, 1158 \mathrm{~s}, 482 \mathrm{~m}, 445 \mathrm{w}$, 252 s $\nu(\mathrm{Ir}-\mathrm{Cl}) .{ }^{1} \mathrm{H}$ NMR $\left(\mathrm{CD}_{3} \mathrm{CN}, 293 \mathrm{~K}\right): \delta, 1.63(\mathrm{~s}, 15 \mathrm{H}$, $\mathrm{CH}_{3 \mathrm{Cp}}$ ), 5.51 (s, $1 \mathrm{H}, \mathrm{C}(1) \mathrm{H}$ of bdcurc), 6.57 (d, $2 \mathrm{H}, \mathrm{C}\left(3,3^{\prime}\right) \mathrm{H}$ of bdcurc, $\left.{ }^{3} J_{\text {trans }}=16 \mathrm{~Hz}\right), 6.87\left(\mathrm{~m}, 4 \mathrm{H}, \mathrm{C}\left(7,7^{\prime}\right) \mathrm{H}\right.$ and $\mathrm{C}\left(9,9^{\prime}\right) \mathrm{H}$ of bdcurc), 7.37 (s, 2H, OH of bdcurc), 7.55 (m, 4H, C(6, 6') H and $\mathrm{C}\left(10,10^{\prime}\right) \mathrm{H}$ of bdcurc), 7.61 (m, $2 \mathrm{H}, \mathrm{C}\left(4,4^{\prime}\right) \mathrm{H}$ of bdcurc). ${ }^{13} \mathrm{C}$ NMR ( $\left.\mathrm{CD}_{3} \mathrm{CN}, 293 \mathrm{~K}\right): \delta, 8.9\left(\mathrm{~s}, \mathrm{CH}_{3 \mathrm{Cp}^{*}}\right), 92.7\left(\mathrm{~s}, C_{\mathrm{Cp}^{*}}\right), 101.6(\mathrm{~s}$, $C(1)$ of bdcurc), 116.6 (s, C(7, $\left.7^{\prime}\right)$ and $\mathrm{C}\left(9,9^{\prime}\right)$ of bdcurc), 121.4 (s, $\mathrm{C}\left(6,6^{\prime}\right.$ and $\left(\mathrm{C}\left(10,10^{\prime}\right)\right.$ of bdcurc), 126.5 (s, $\mathrm{C}\left(5,5^{\prime}\right)$ of bdcurc), 131.0 (s, C(4, 4') of bdcurc), 141.0 (s, C(3, 3') of bdcurc), 160.5 (s, C(8, 8') of bdcurc), 183.8 (s, C(2, 2')=O of bdcurc). ESI-MS $(+) \mathrm{CH}_{3} \mathrm{CN}(\mathrm{m} / \mathrm{z}$, relative intensity \%): 635 $[100]\left[\mathrm{Cp}^{*} \operatorname{Ir}(\text { bdcurc })\right]^{+}$.

$\left[\mathbf{C p}^{*} \mathbf{R h}\right.$ (curc)(PTA)][ $\left.\mathrm{SO}_{3} \mathrm{CF}_{3}\right] \quad$ (5). $\mathrm{AgSO}_{3} \mathrm{CF}_{3} \quad(64 \quad \mathrm{mg}$, $0.25 \mathrm{mmol}$ ) was added to a solution of $1(160 \mathrm{mg}, 0.25 \mathrm{mmol})$ in acetonitrile. The reaction mixture was stirred for $1 \mathrm{~h}$ and filtered to remove AgCl. PTA was added and the reaction was carried out for $24 \mathrm{~h}$ at room temperature. The solvent was removed under reduced pressure and methanol and diethyl ether $(20 \mathrm{~mL})$ was added. The mixture was left at $4{ }^{\circ} \mathrm{C}$ until an orange precipitate formed. The orange crystalline powder was recovered by filtration and air-dried $(154.9 \mathrm{mg}, 0.169 \mathrm{mmol}$, yield 68\%) and it was identified as 5. It is soluble in alcohols, acetone, acetonitrile, DMSO and slightly soluble in chlorinated solvents and water. M.p. 253-254 ${ }^{\circ} \mathrm{C}$. Anal. Calcd for $\mathrm{C}_{38} \mathrm{H}_{46} \mathrm{~F}_{3} \mathrm{~N}_{3} \mathrm{O}_{9} \mathrm{PRhS}$ : C, 50.06; H, 5.09; N, 4.61. Found: C, 50.00; $\mathrm{H}, 5.01 ; \mathrm{N}, 4.55$. IR ( $\left.\mathrm{cm}^{-1}\right): 3258 \mathrm{w}, 2925 \mathrm{w}, 1621 \mathrm{sh}, 1601 \mathrm{~m}$, $1583 \mathrm{~m} \nu(\mathrm{C}=\mathrm{C}), 1496 \mathrm{~s}, 1270 \mathrm{~s}, 1148 \mathrm{~s}, 1029 \mathrm{~s} \nu\left(\mathrm{SO}_{3} \mathrm{CF}_{3}\right)$, $570 \mathrm{~m} \nu(\mathrm{Rh}-\mathrm{P}), 472 \mathrm{~m}, 454 \mathrm{w}, 421 \mathrm{w} \nu(\mathrm{Rh}-\mathrm{P}) .{ }^{1} \mathrm{H}$ NMR $\left(\mathrm{CD}_{3} \mathrm{CN}\right.$, $293 \mathrm{~K}): \delta, 1.68\left(\mathrm{~d}, 15 \mathrm{H}, \mathrm{CH}_{3 \mathrm{Cp}^{*}}, J_{\mathrm{HP}}=3.4 \mathrm{~Hz}\right), 3.94\left(\mathrm{~s}, 6 \mathrm{H}, \mathrm{OCH}_{3}\right.$ of curc), 4.17 (s, 6H, $\left.\mathrm{NCH}_{2} \mathrm{~N}, \mathrm{PTA}\right), 4.49$ (s, 6H, $\left.\mathrm{PCH}_{2} \mathrm{~N}, \mathrm{PTA}\right)$, $5.65\left(\mathrm{~s}, 1 \mathrm{H}, \mathrm{C}(1) \mathrm{H}\right.$ of curc), $6.76\left(\mathrm{~d}, 2 \mathrm{H}, \mathrm{C}\left(3,3^{\prime}\right) \mathrm{H}\right.$ of curc, $\left.{ }^{3} J_{\text {trans }}=16 \mathrm{~Hz}\right), 6.89\left(\mathrm{~d}, 2 \mathrm{H}, \mathrm{C}\left(9,9^{\prime}\right) \mathrm{H}\right.$ of curc, $\left.{ }^{3} J_{\text {aromH-H }}=8 \mathrm{~Hz}\right)$, 6.95 (sbr, $2 \mathrm{H}, \mathrm{OH}$ of curc), 7.16 (dd, $2 \mathrm{H}, \mathrm{C}\left(10,10^{\prime}\right) \mathrm{H}$ of curc, $\left.{ }^{3} J_{\text {aromH-H }}=8 \mathrm{~Hz}\right), 7.28\left(\mathrm{~s}, 2 \mathrm{H}, \mathrm{C}\left(6,6^{\prime}\right) \mathrm{H}\right.$ of curc), $7.61(\mathrm{~d}, 2 \mathrm{H}$, $\mathrm{C}\left(4,4^{\prime}\right) \mathrm{H}$ of curc $\left.{ }^{3} J_{\text {trans }}=16 \mathrm{~Hz}\right) \cdot{ }^{13} \mathrm{C} \mathrm{NMR}\left(\mathrm{CD}_{3} \mathrm{CN}, 293 \mathrm{~K}\right): \delta$, $7.2\left(\mathrm{~s}, \mathrm{CH}_{3 \mathrm{Cp}^{*}}\right), 47.8\left(\mathrm{~d}, \mathrm{NCH}_{2} \mathrm{P}, \mathrm{PTA}, J_{\mathrm{CP}}=11.1 \mathrm{~Hz}\right), 54.8(\mathrm{~s}$, $\mathrm{OCH}_{3}$ of curc), $71.3\left(\mathrm{~d}, \mathrm{NCH}_{2} \mathrm{~N}, \mathrm{PTA}, J_{\mathrm{CP}}=6.9 \mathrm{~Hz}\right), 97.9$ (d,
$\left.\mathrm{C}_{\mathrm{Cp}^{*}}, J\left({ }^{103} \mathrm{Rh}-{ }^{13} \mathrm{C}\right)=6.8 \mathrm{~Hz}\right), 102.7(\mathrm{~s}, C(1)$ of curc $), 109.5(\mathrm{~s}$, $\mathrm{C}\left(6,6^{\prime}\right)$ of curc), 114.0 (s, C(9, 9') of curc), 121.8 (s, C(10, 10') of curc), 124.4 (s, C(5, 5') of curc), 126.9 (s, C(3, 3') of curc), 139.0 (s, C(4, 4') of curc), 146.7 (s, C(7, 7') of curc), 147.4 (s, C(8, 8') of curc), $179.2\left(\mathrm{~s}, \mathrm{C}\left(2,2^{\prime}\right)=\mathrm{O}\right.$ of curc). ${ }^{31} \mathrm{P} \mathrm{NMR}\left(\mathrm{CD}_{3} \mathrm{CN}\right.$, $293 \mathrm{~K}): \delta=-34.9\left(\mathrm{~d}, J_{\mathrm{PRh}}=151 \mathrm{~Hz}, \mathrm{PTA}\right)$. ESI-MS $(+) \mathrm{CH}_{3} \mathrm{CN}$ $\left(\mathrm{m} / \mathrm{z}\right.$, relative intensity \%): $605[100]\left[\mathrm{Cp}^{*} \mathrm{Rh}(\text { curc })\right]^{+}, 762[10]$ $\left[\mathrm{Cp}^{*} \mathrm{Rh}(\text { curc })(\mathrm{PTA})\right]^{+}$.

$\left[\left(\mathbf{C p}^{*}\right) \mathbf{R h}(\right.$ bdcurc)(PTA) $]\left[\mathrm{SO}_{3} \mathbf{C F}_{3}\right]$ (6). Compound 6 was prepared following a procedure similar to that reported for 5 by using precursor 2 (129.8 $\mathrm{mg}, 0.15 \mathrm{mmol}$, yield 61\%). 6 is soluble in alcohols, acetone, acetonitrile, DMSO, chlorinated solvents and slightly soluble in water. M.p. 237-239 ${ }^{\circ} \mathrm{C}$. Anal. Calcd for $\mathrm{C}_{36} \mathrm{H}_{42} \mathrm{~F}_{3} \mathrm{~N}_{3} \mathrm{O}_{7} \mathrm{PRhS}: \mathrm{C}, 50.77 ; \mathrm{H}, 4.97 ; \mathrm{N}, 4.93$. Found: C, 50.68; H, 4.86; N, 4.82. IR $\left(\mathrm{cm}^{-1}\right)$ : 3157 br, $1617 \mathrm{sh}$, $1602 \mathrm{~m}, 1588 \mathrm{~m} \nu(\mathrm{C}=\mathrm{C}), 1493 \mathrm{~s}, 1277 \mathrm{~s}, 1160 \mathrm{~s}, 1025 \mathrm{~s}$ $\nu\left(\mathrm{SO}_{3} \mathrm{CF}_{3}\right), 580 \mathrm{~m}, 571 \mathrm{~m} \nu(\mathrm{Rh}-\mathrm{P}), 476 \mathrm{~s}, 450 \mathrm{w}, 346 \mathrm{w} \nu(\mathrm{Rh}-\mathrm{P})$. ${ }^{1} \mathrm{H}$ NMR $\left(\mathrm{CD}_{3} \mathrm{CN}, 293 \mathrm{~K}\right): \delta, 1.67\left(\mathrm{~d}, 15 \mathrm{H}, \mathrm{CH}_{3 \mathrm{Cp}^{*}}, J_{\mathrm{HP}}=3.4 \mathrm{~Hz}\right)$, 4.16 (s, 6H, $\left.\mathrm{NCH}_{2} \mathrm{~N}, \mathrm{PTA}\right), 4.48$ (s, 6H, $\left.\mathrm{PCH}_{2} \mathrm{~N}, \mathrm{PTA}\right), 5.65$ (s, $1 \mathrm{H}, \mathrm{C}(1) \mathrm{H}$ of bdcurc), $6.71\left(\mathrm{~d}, 2 \mathrm{H}, \mathrm{C}\left(3,3^{\prime}\right) \mathrm{H}\right.$ of bdcurc, ${ }^{3} J_{\text {trans }}=$ $16 \mathrm{~Hz}), 6.88\left(\mathrm{~m}, 4 \mathrm{H}, \mathrm{C}\left(7,7^{\prime}\right) \mathrm{H}\right.$ and $\mathrm{C}\left(9,9^{\prime}\right) \mathrm{H}$ of bdcurc), 7.40 (s, $2 \mathrm{H}, \mathrm{OH}$ of bdcurc), $7.55\left(\mathrm{~m}, 4 \mathrm{H}, \mathrm{C}\left(6,6^{\prime}\right) \mathrm{H}\right.$ and $\mathrm{C}\left(10,10^{\prime}\right) \mathrm{H}$ of bdcurc), 7.62 (d, 2H, C $\left(4,4^{\prime}\right) \mathrm{H}$ of bdcurc, $\left.{ }^{3} J_{\text {trans }}=16 \mathrm{~Hz}\right) \cdot{ }^{13} \mathrm{C}$ NMR ( $\left.\mathrm{CD}_{3} \mathrm{CN}, 293 \mathrm{~K}\right): \delta, 8.5\left(\mathrm{~s}, \mathrm{CH}_{3 \mathrm{Cp}^{*}}\right), 48.8\left(\mathrm{~d}, \mathrm{NCH}_{2} \mathrm{P}, \mathrm{PTA}\right.$, $\left.J_{\mathrm{CP}}=9.9 \mathrm{~Hz}\right), 72.5\left(\mathrm{~d}, \mathrm{NCH}_{2} \mathrm{~N}, \mathrm{PTA}, J_{\mathrm{CP}}=11.1 \mathrm{~Hz}\right), 91.6\left(\mathrm{~s}, C_{\mathrm{Cp}^{*}}\right)$ $\left(\mathrm{d}, \mathrm{C}_{\mathrm{Cp}}, J\left({ }^{103} \mathrm{Rh}^{-13} \mathrm{C}\right)=7.0 \mathrm{~Hz}\right), 104.0(\mathrm{~s}, C(1)$ of bdcurc $), 116.1$ (s, C(7, $\left.7^{\prime}\right)$ and $\mathrm{C}\left(9,9^{\prime}\right)$ of bdcurc), 125.4 (s, C(6, 6') and $\mathrm{C}(10$, $\left.10^{\prime}\right)$ of bdcurc), 127.6 (s, C(5, 5') of bdcurc), 130.2 (s, C(4, 4') of bdcurc), 139.9 (s, C(3, 3') of bdcurc), 159.8 (s, C(8, 8') of bdcurc), 178.4 (s, $\mathrm{C}\left(2,2^{\prime}\right)=\mathrm{O}$ of bdcurc). ${ }^{31} \mathrm{P} \mathrm{NMR}\left(\mathrm{CD}_{3} \mathrm{CN}\right.$, $293 \mathrm{~K}): \delta=-34.9\left(\mathrm{~d}, J_{\mathrm{PRh}}=151 \mathrm{~Hz}, \mathrm{PTA}\right)$. ESI-MS $(+) \mathrm{CH}_{3} \mathrm{CN}$ $\left(\mathrm{m} / z\right.$, relative intensity \%): $545[100]\left[\mathrm{Cp}^{*} \mathrm{Rh}(\text { bdcurc })\right]^{+}, 702[10]$ $\left[\mathrm{Cp}^{*} \mathrm{Rh}(\text { bdcurc })(\mathrm{PTA})\right]^{+}$.

$\left[\mathbf{C p}^{*} \operatorname{Ir}(\right.$ curc)(PTA) $]\left[\mathbf{S O}_{3} \mathbf{C F}_{3}\right]$ (7). Compound 7 was prepared following a procedure similar to that reported for 5 by using precursor 3 (157.66 mg, $0.15 \mathrm{mmol}$, yield 63\%). 7 is soluble in alcohols, acetone, acetonitrile, DMSO and slightly soluble in chlorinated solvents and water. M.p. 227-229 ${ }^{\circ} \mathrm{C}$. Anal. Calcd for $\mathrm{C}_{38} \mathrm{H}_{46} \mathrm{~F}_{3} \mathrm{IrN}_{3} \mathrm{O}_{9} \mathrm{PS}$ : C, 45.59; $\mathrm{H}, 4.63$; N, 4.20. Found: C, 45.50; H, 4.57; N, 4.14. IR ( $\left.\mathrm{cm}^{-1}\right)$ : $2924 \mathrm{br}, 1613 \mathrm{sh}, 1599 \mathrm{~m}$, $1584 \mathrm{~m} \nu(\mathrm{C}=\mathrm{C}), 1493 \mathrm{~s}, 1270 \mathrm{~s}, 1149 \mathrm{~s}, 1028 \mathrm{~s} \nu\left(\mathrm{SO}_{3} \mathrm{CF}_{3}\right)$, $575 \mathrm{~m} \nu$ (Ir-P), $472 \mathrm{~m}, 453 \mathrm{w}, 390 \mathrm{w} \nu(\mathrm{Ir}-\mathrm{P}) .{ }^{1} \mathrm{H}$ NMR $\left(\mathrm{CD}_{3} \mathrm{CN}\right.$, $293 \mathrm{~K}): \delta, 1.70\left(\mathrm{~d}, 15 \mathrm{H}, \mathrm{CH}_{3 \mathrm{Cp}^{*}}, J_{\mathrm{HP}}=1.9 \mathrm{~Hz}\right) .3 .94\left(\mathrm{~s}, 6 \mathrm{H}, \mathrm{OCH}_{3}\right.$ of curc), 4.16 (s, 6H, $\left.\mathrm{NCH}_{2} \mathrm{~N}, \mathrm{PTA}\right), 4.48\left(\mathrm{~m}, 6 \mathrm{H}, \mathrm{PCH}_{2} \mathrm{~N}, \mathrm{PTA}\right)$, $5.71\left(\mathrm{~s}, 1 \mathrm{H}, \mathrm{C}(1) \mathrm{H}\right.$ of curc), $6.69\left(\mathrm{~d}, 2 \mathrm{H}, \mathrm{C}\left(3,3^{\prime}\right) \mathrm{H}\right.$ of curc, $\left.{ }^{3} J_{\text {trans }}=16 \mathrm{~Hz}\right), 6.89\left(\mathrm{~d}, 2 \mathrm{H}, \mathrm{C}\left(9,9^{\prime}\right) \mathrm{H}\right.$ of curc, ${ }^{3} J_{\text {aromH-H }}=$ $8 \mathrm{~Hz})$ ), 7.04 (s, 2H, OH of curc), $7.18\left(\mathrm{dd}, 2 \mathrm{H}, \mathrm{C}\left(10,10^{\prime}\right) \mathrm{H}\right.$ of curc, $\left.{ }^{3} J_{\text {aromH-H }}=8 \mathrm{~Hz}\right), 7.30\left(\mathrm{~s}, 2 \mathrm{H}, \mathrm{C}\left(6,6^{\prime}\right) \mathrm{H}\right.$ of curc), 7.63 (d, $2 \mathrm{H}, \mathrm{C}\left(4,4^{\prime}\right) \mathrm{H}$ of curc, $\left.{ }^{3} J_{\text {trans }}=16 \mathrm{~Hz}\right) \cdot{ }^{13} \mathrm{C} \mathrm{NMR}\left(\mathrm{CDCl}_{3}, 293 \mathrm{~K}\right)$ : $\delta, 9.4\left(\mathrm{~s}, \mathrm{CH}_{3 \mathrm{Cp}^{*}}\right), 49.4\left(\mathrm{~d}, \mathrm{PCH}_{2} \mathrm{~N}, \mathrm{PTA}, J_{\mathrm{CP}}=18.8 \mathrm{~Hz}\right), 57.1(\mathrm{~s}$, $\mathrm{OCH}_{3}$ of curc), $73.6\left(\mathrm{~d}, \mathrm{NCH}_{2} \mathrm{~N}, \mathrm{PTA}, J_{\mathrm{CP}}=7.1 \mathrm{~Hz}\right), 93.5(\mathrm{~s}$, $\left.C_{\mathrm{CP}^{*}}\right), 105.9$ (s, C(1) of curc), 111.7 (C(6, 6') of curc), $116.4(\mathrm{C}(9$, $\left.9^{\prime}\right)$ of curc), 124.1 (C(10,10') of curc), 125.7 ( $\left(5,55^{\prime}\right)$ of curc), $129.2\left(\mathrm{C}\left(3,3^{\prime}\right)\right.$ of curc), $141.4\left(\mathrm{C}\left(4,4^{\prime}\right)\right.$ of curc $), 149.0\left(\mathrm{C}\left(7,7^{\prime}\right)\right.$ of curc), 149.7 (C(8, 8') of curc), $179.5\left(\mathrm{C}\left(2,2^{\prime}\right)=\mathrm{O}\right.$ of curc $)$. ${ }^{31} \mathrm{P}$ NMR $\left(\mathrm{CD}_{3} \mathrm{CN}, 293 \mathrm{~K}\right): \delta=-56.1$ (s, PTA). ESI-MS $(+) \mathrm{CH}_{3} \mathrm{CN}$ 
$\left(\mathrm{m} / \mathrm{z}\right.$, relative intensity \%): $695.2[100]\left[\mathrm{Cp}^{*} \operatorname{Ir}(\mathrm{curc})\right]^{+}, 852[30]$ $\left[\mathrm{Cp}^{*} \operatorname{Ir}(\text { curc)(PTA })\right]^{+}$.

[Cp* $\operatorname{Ir}\left(\right.$ bdcurc)(PTA)][$\left[\mathrm{SO}_{3} \mathrm{CF}_{3}\right]$ (8). Compound 8 was prepared following a procedure similar to that reported for $\mathbf{5}$ by using precursor 4 (152.91 $\mathrm{mg}, 0.16 \mathrm{mmol}$, yield $65 \%) .8$ is soluble in alcohols, acetone, acetonitrile and DMSO. M.p. 249-251 ${ }^{\circ} \mathrm{C}$. Anal. Calcd for $\mathrm{C}_{36} \mathrm{H}_{42} \mathrm{~F}_{3} \operatorname{IrN}_{3} \mathrm{O}_{7}$ PS: C, 45.95; H, 4.50; N, 4.47. Found: C, 45.83; H, 4.44; N, 4.41. IR $\left(\mathrm{cm}^{-1}\right)$ : $3155 \mathrm{br}, 1615 \mathrm{sh}, 1602 \mathrm{~m}, 1586 \mathrm{~m} \nu(\mathrm{C}=\mathrm{C}), 1491 \mathrm{~s}, 1278 \mathrm{~s}, 1160$ s, $1025 \mathrm{~s} \nu\left(\mathrm{SO}_{3} \mathrm{CF}_{3}\right), 600 \mathrm{~m}, 577 \mathrm{~m} \nu(\mathrm{Ir}-\mathrm{P}), 482 \mathrm{~s}, 456 \mathrm{w}, 346 \mathrm{w}$ $\nu(\mathrm{Ir}-\mathrm{P}) .{ }^{1} \mathrm{H}$ NMR $\left(\mathrm{CD}_{3} \mathrm{CN}, 293 \mathrm{~K}\right): \delta, 1.69\left(\mathrm{~d}, 15 \mathrm{H}, \mathrm{CH}_{3 \mathrm{Cp}^{*}}, J_{\mathrm{HP}}=\right.$ $2.0 \mathrm{~Hz}), 4.16\left(\mathrm{~s}, 6 \mathrm{H}, \mathrm{NCH}_{2} \mathrm{~N}, \mathrm{pta}\right), 4.48\left(\mathrm{~m}, 6 \mathrm{H}, \mathrm{PCH}_{2} \mathrm{~N}, \mathrm{pta}\right)$, $5.71\left(\mathrm{~s}, 1 \mathrm{H}, \mathrm{C}(1) \mathrm{H}\right.$ of bdcurc), $6.63\left(\mathrm{~d}, 2 \mathrm{H}, \mathrm{C}\left(3,3^{\prime}\right) \mathrm{H}\right.$ of bdcurc, $\left.{ }^{3} J_{\text {trans }}=16 \mathrm{~Hz}\right), 6.88\left(\mathrm{~m}, 4 \mathrm{H}, \mathrm{C}\left(7,7^{\prime}\right) \mathrm{H}\right.$ and $\mathrm{C}\left(9,9^{\prime}\right) \mathrm{H}$ of bdcurc $)$, $7.44\left(\mathrm{~s}, 2 \mathrm{H}, \mathrm{OH}\right.$ of bdcurc), $7.57\left(\mathrm{~m}, 4 \mathrm{H}, \mathrm{C}\left(6,6^{\prime}\right) \mathrm{H}\right.$ and $\mathrm{C}(10$, $\left.10^{\prime}\right) \mathrm{H}$ of bdcurc), $7.64\left(\mathrm{~d}, 2 \mathrm{H}, \mathrm{C}\left(4,4^{\prime}\right) \mathrm{H}\right.$ of bdcurc, ${ }^{3} J_{\text {trans }}=16$ $\mathrm{Hz}) .{ }^{13} \mathrm{C}$ NMR $\left(\mathrm{CD}_{3} \mathrm{CN}, 293 \mathrm{~K}\right): \delta, 8.5\left(\mathrm{~s}, \mathrm{CH}_{3 \mathrm{Cp}^{*}}\right), 48.1(\mathrm{~d}$, $\left.\mathrm{PCH}_{2} \mathrm{~N}, \mathrm{PTA}, J_{\mathrm{CP}}=18.4 \mathrm{~Hz}\right), 72.5\left(\mathrm{~d}, \mathrm{NCH}_{2} \mathrm{~N}, \mathrm{PTA}, J_{\mathrm{CP}}=7.7 \mathrm{~Hz}\right)$, $92.4\left(\mathrm{~s}, C_{\mathrm{Cp}^{*}}\right), 105.0\left(\mathrm{~s}, C(1)\right.$ of bdcurc), $116.2\left(\mathrm{~s}, \mathrm{C}\left(7,7^{\prime}\right)\right.$ and $\mathrm{C}\left(9,9^{\prime}\right)$ of bdcurc), 124.4 (s, C(6, 6') and $\mathrm{C}\left(10,10^{\prime}\right)$ of bdcurc), 127.7 (s, C(5, 5') of bdcurc), 130.2 (s, C $\left(4,4^{\prime}\right)$ of bdcurc), 140.1 (s, C( $\left.3,3^{\prime}\right)$ of bdcurc), 159.2 (s, C(8, 8') of bdcurc), 178.4 (s, C(2, $\left.2^{\prime}\right)=\mathrm{O}$ of bdcurc). ${ }^{31} \mathrm{P}$ NMR $\left(\mathrm{CD}_{3} \mathrm{CN}, 293 \mathrm{~K}\right): \delta=-56.3$ (s, PTA). ESI-MS $(+) \mathrm{CH}_{3} \mathrm{CN}(\mathrm{m} / z$, relative intensity \%): 635 [100] [Cp*Ir(bdcurc) $]^{+}, 792[20]\left[\mathrm{Cp}^{*} \operatorname{Ir}(\text { bdcurc)(PTA) }]^{+}\right.$.

\section{$\mathrm{X}$-ray crystal structure determination}

Diffraction data were measured at low temperature [100(2) K] using Mo $\mathrm{K}_{\alpha}$ radiation on a Bruker APEX II CCD diffractometer equipped with a kappa geometry goniometer. The datasets were reduced by using EvalCCD ${ }^{61}$ and then corrected for absorption. ${ }^{62}$ The solutions and refinements were performed by using SHELX. ${ }^{63}$ The crystal structures were refined using full-matrix least-squares based on $F^{2}$ with all non-hydrogen atoms anisotropically defined. Hydrogen atoms were placed in calculated positions by means of the "riding" model. Disorder problems dealing with $\mathrm{CF}_{3} \mathrm{SO}_{3}{ }^{-}$were encountered during the last stages of refinement and treated by using the split model (SADI and SIMU cards were applied to retain a reasonable geometry and acceptable ADP).

\section{Cell culture and inhibition of cell growth}

The human A2780 and A2780cisR ovarian carcinoma and HEK (human embryonic kidney) cells were obtained from the European Collection of Cell Cultures (Salisbury, U.K.). A2780 and A2780cisR cells were grown routinely in RPMI-1640 medium, while HEK cells were grown in DMEM medium, with $10 \%$ fetal bovine serum (FBS) and $1 \%$ antibiotics at $37{ }^{\circ} \mathrm{C}$ and $5 \% \mathrm{CO}_{2}$. Cytotoxicity was determined using the MTT assay (MTT $=3$-(4,5-dimethyl-2-thiazolyl)-2,5diphenyl- $2 H$-tetrazolium bromide). The cells were seeded in 96-well plates as monolayers with $100 \mu \mathrm{L}$ of cell suspension (approximately 5000 cells) per well and pre-incubated for $24 \mathrm{~h}$ in a medium supplemented with $10 \%$ FBS. Compounds were prepared as DMSO solutions and then dissolved in the culture medium and serially diluted to the appropriate concentration, to give a final DMSO concentration of $0.5 \% .100 \mu \mathrm{L}$ of the drug solution was added to each well, and the plates were incubated for another $72 \mathrm{~h}$. Subsequently, MTT ( $5 \mathrm{mg} \mathrm{mL}^{-1}$ solution) was added to the cells and the plates were incubated for a further $2 \mathrm{~h}$. The culture medium was aspirated, and the purple formazan crystals formed by the mitochondrial dehydrogenase activity of vital cells were dissolved in DMSO. The optical density, directly proportional to the number of surviving cells, was quantified at $590 \mathrm{~nm}$ using a multiwell plate reader, and the fraction of surviving cells was calculated from the absorbance of untreated control cells. Evaluation is based on means from at least two independent experiments, each comprising triplicates per concentration level.

\section{Determination of $\mathrm{p} K_{\mathrm{a}}$ values}

The $\mathrm{pH}$ values of NMR samples in $\mathrm{D}_{2} \mathrm{O}$ were measured at $298 \mathrm{~K}$, directly in the NMR tube, using a $713 \mathrm{pH}$ meter (Metrohm) equipped with an electrode calibrated with buffer solutions at $\mathrm{pH}$ values of 4,7 , and 9 . The $\mathrm{pH}$ values were adjusted with dilute $\mathrm{HNO}_{3}$ and $\mathrm{NaOH}$. The $\mathrm{pH}$ titration curves were fitted to the Henderson-Hasselbalch equation using the program Matlab (MathWorks Software) with the assumption that the observed chemical shifts are weighted averages according to the populations of the protonated and deprotonated species. The resonance frequencies change smoothly with $\mathrm{pH}$ between the chemical shifts of the charged form $\mathrm{HA}^{+}$, stable in acidic solution, and those of the neutral, deprotonated form $\mathrm{A}$, which is present at a high $\mathrm{pH}$. At any $\mathrm{pH}$, the observed chemical shift is a weighted average $\left(\delta_{\mathrm{av}}\right)$ of the two extreme values $\delta\left(\mathrm{HA}^{+}\right)$and $\delta(\mathrm{A})$ :

$$
\delta_{\mathrm{av}}=\frac{\delta\left(\mathrm{HA}^{+}\right)\left[\mathrm{HA}^{+}\right]+\delta(\mathrm{A})[\mathrm{A}]}{\left[\mathrm{HA}^{+}\right]+[\mathrm{A}]}
$$

The midpoint of the titration occurs when the concentrations of the acid and its conjugate base are equal: $\left[\mathrm{HA}^{+}\right]=$ [A], that is, when the $\mathrm{pH}$ equals the $\mathrm{p} K_{\mathrm{a}}$ of the compound. The $\mathrm{pH}$ at the midpoint of the curve is corrected by subtracting 0.44 to the $\mathrm{pD}$ values since the measurements were made in $\mathrm{D}_{2} \mathrm{O} .{ }^{64}$

\section{Acknowledgements}

This work was financially supported by the University of Camerino (Fondo di Ateneo per la Ricerca 2011-2012), by MIUR (PRIN 2010-2011; 2010BNZ3F2) and by COST (CM 1302, European Network on Smart Inorganic Polymers).

\section{Notes and references}

1 B. B. Aggarwal, C. Sundaram, N. Malani and H. Ichikawa, Curcumin: the Indian solid gold, in The molecular targets and therapeutic uses of curcumin in health and disease, Springer, USA, 2007, pp. 1-75. 
2 A. K. Renfrew, N. S. Bryce and T. W. Hambley, Chem. Sci., 2013, 4, 3731-3739.

3 S. Banerjee, P. Prasad, A. Hussain, I. Khan, P. Kondaiah and A. R. Chakravarty, Chem. Commun., 2012, 48, 77027704.

4 M. Sagnou, D. Benaki, C. Triantis, T. Tsotakos, V. Psycharis, C. P. Raptopoulou, I. Pirmettis, M. Papadopoulos and M. Pelecanou, Inorg. Chem., 2011, 50, 1295-1303.

5 G. Bar-Sela, R. Epelbaum and M. Schaffer, Curr. Med. Chem., 2010, 17, 190-197.

6 R. Waranyoupalin, S. Wongnawa, M. Wongnawa, C. Pakawatchai, P. Panichayupakaranant and P. Sherdshoopongse, Cent. Eur. J. Chem., 2009, 7, 388-394.

7 A. Goel, A. B. Kunnumakkara and B. B. Aggarwal, Biochem. Pharmacol., 2008, 75, 787-809.

8 P. Anand, A. B. Kunnumakkara, R. A. Newman and B. B. Aggarwal, Mol. Pharm., 2007, 4, 807-818.

9 A. Arezki, G. G. Chabot, L. Quentin, D. Scherman, G. Jaouen and E. Brulé, MedChemComm, 2011, 2, 190-195.

10 A. Arezki, E. Brule and G. Jaouen, Organometallics, 2009, 28, 1606-1609.

11 S. Wanninger, V. Lorenz, A. Subhan and F. T. Edelmann, Chem. Soc. Rev., 2015, 44, 4986-5002.

12 A. Valentini, F. Conforti, A. Crispini, A. De Martino, R. Condello, C. Stellitano, G. Rotilio, M. Ghedini, G. Federici, S. Bernardini and D. Pucci, J. Med. Chem., 2009, 52, 484-491.

13 B. Balaji, B. Balakrishnan, S. Perumalla, A. A. Karande and A. R. Chakravarty, Eur. J. Med. Chem., 2014, 85, 458-467.

14 S. K. Singh and D. S. Pandey, RSC Adv., 2014, 4, 18191840.

15 G. Sava, A. Bergamo and P. J. Dyson, Dalton Trans., 2011, 40, 9069-9075.

16 E. Meggers, Angew. Chem., Int. Ed., 2011, 50, 2442-2448.

17 G. S. Smith and B. Therrien, Dalton Trans., 2011, 40, 10793-10800.

18 G. Gasser, I. Ott and N. Metzler-Nolte, J. Med. Chem., 2011, 54, 3-25.

19 A. L. Noffke, A. Habtemariam, A. M. Pizarro and P. J. Sadler, Chem. Commun., 2012, 48, 5219-5246.

20 N. P. E. Barry and P. J. Sadler, Chem. Commun., 2013, 49, 5106-5131.

21 C. G. Hartinger, M. Groessl, S. M. Meier, A. Casini and P. J. Dyson, Chem. Soc. Rev., 2013, 42, 6186-6199.

22 F. Caruso, M. Rossi, A. Benson, C. Opazo, D. Freedman, E. Monti, M. B. Gariboldi, J. Shaulky, F. Marchetti, R. Pettinari and C. Pettinari, J. Med. Chem., 2012, 55, 10721081.

23 L. Bonfili, R. Pettinari, M. Cuccioloni, V. Cecarini, M. Mozzicafreddo, M. Angeletti, G. Lupidi, F. Marchetti, C. Pettinari and A. M. Eleuteri, ChemMedChem, 2012, 7, 2010-2020.

24 R. Pettinari, F. Marchetti, F. Condello, C. Pettinari, G. Lupidi, R. Scopelliti, S. Mukhopadhyay, T. Riedel and P. J. Dyson, Organometallics, 2014, 33, 3709-3715.
25 T. Giraldi, G. Sava, G. Mestroni, G. Zassinovich and D. Stolfa, Chem.-Biol. Interact., 1978, 22, 231-238.

26 G. Sava, S. Zorzet, L. Perissin, G. Mestroni, G. Zassinovich and A. Bontempi, Inorg. Chim. Acta, 1987, 137, 69-71.

27 C. Pettinari, R. Pettinari, M. Fianchini, F. Marchetti, B. W. Skelton and A. H. White, Inorg. Chem., 2005, 44, 7933-7942.

28 C. Pettinari, R. Pettinari, F. Marchetti, A. Macchioni, D. Zuccaccia, B. W. Skelton and A. H. White, Inorg. Chem., 2007, 46, 896-906.

29 Z. Liu and P. J. Sadler, Acc. Chem. Res., 2014, 47, 11741185.

30 M. Gras, B. Therrien, G. Süss-Fink, A. Casini, F. Edafe and P. J. Dyson, J. Organomet. Chem., 2010, 695, 1119-1125.

31 Z. Liu, A. Habtemariam, A. M. Pizarro, G. J. Clarkson and P. J. Sadler, Organometallics, 2011, 30, 4702-4710.

32 Z. Liu, L. Salassa, A. Habtemariam, A. M. Pizarro, G. J. Clarkson and P. J. Sadler, Inorg. Chem., 2011, 50, 5777-5783.

33 Z. Liu, A. Habtemariam, A. M. Pizarro, S. A. Fletcher, A. Kisova, O. Vrana, L. Salassa, P. C. A. Bruijnincx, G. J. Clarkson, V. Brabec and P. J. Sadler, J. Med. Chem., 2011, 54, 3011-3026.

34 Y. Geldmacher, K. Splith, I. Kitanovic, H. Alborzinia, S. Can, R. Rubbiani, M. A. Nazif, P. Wefelmeier, A. Prokop, I. Ott, S. Wölfl, I. Neundorf and W. S. Sheldrick, J. Biol. Inorg. Chem., 2012, 17, 631-646.

35 M. A. Nazif, R. Rubbiani, H. Alborzinia, I. Kitanovic, S. Wölfl, I. Ott and W. S. Sheldrick, Dalton Trans., 2012, 41, 5587-5598.

36 N. P. E. Barry and P. J. Sadler, Chem. Soc. Rev., 2012, 41, 3264-3279.

37 R. Payne, P. Govender, B. Therrien, C. M. Clavel, P. J. Dyson and G. S. Smith, J. Organomet. Chem., 2013, 729, 20-27.

38 M. U. Raja, J. Tauchman, B. Therrien, G. Süss-Fink, T. Riedel and P. J. Dyson, Inorg. Chim. Acta, 2014, 409, 479483.

39 L. C. Sudding, R. Payne, P. Govender, F. Edafe, C. M. Clavel, P. J. Dyson, B. Therrien and G. S. Smith, J. Organomet. Chem., 2014, 774, 79-85.

40 V. Novohradsky, Z. Liu, M. Vojtiskova, P. J. Sadler, V. Brabec and J. Kasparkova, Metallomics, 2014, 6, 682-690.

41 F. Kühlwein, K. Polborn and W. Beck, Z. Anorg. Allg. Chem., 1997, 623, 1211-1219.

42 Y. Nakamura, K. Isobe, H. Morita, S. Yamazaki and S. Kawaguchi, Inorg. Chem., 1972, 11, 1573-1578.

43 Z. Liu, I. Romero-Canelón, A. Habtemariam, G. J. Clarkson and P. J. Sadler, Organometallics, 2014, 33, 53245333.

44 K. Nakamoto, Infrared and Raman Spectra of Inorganic and Coordination Compounds: Part B: Applications in Coordination, Organometallic, and Bioinorganic Chemistry, John Wiley \& Sons, Inc., 2008.

45 R. Wanke, P. Smoleński, M. F. C. Guedes Da Silvan, L. M. D. R. S. Martins and A. J. L. Pombeiro, Inorg. Chem., 2008, 47, 10158-10168. 
46 A. Dorcier, W. H. Ang, S. Bolano, L. Gonsalvi, L. JuilleratJeannerat, G. Laurenczy, M. Peruzzini, A. D. Phillips, F. Zanobini and P. J. Dyson, Organometallics, 2006, 25, 4090-4096.

47 M. Erlandsson, V. R. Landaeta, L. Gonsalvi, M. Peruzzini, A. D. Phillips, P. J. Dyson and G. Laurenczy, Eur. J. Inorg. Chem., 2008, 620-627, DOI: 10.1002/ejic.200700792.

48 S. Bolaño, M. Plaza, J. Bravo, J. Castro, M. Peruzzini, L. Gonsalvi, G. Ciancaleoni and A. Macchioni, Inorg. Chim. Acta, 2010, 363, 509-516.

49 R. Pettinari, C. Pettinari, F. Marchetti, M. Monari, E. Mosconi and F. De Angelis, Organometallics, 2013, 32, 3895-3902.

50 E. Carmona, A. Cingolani, F. Marchetti, C. Pettinari, R. Pettinari, B. W. Skelton and A. H. White, Organometallics, 2003, 22, 2820-2826.

51 C. Scolaro, A. Bergamo, L. Brescacin, R. Delfino, M. Cocchietto, G. Laurenczy, T. J. Geldbach, G. Sava and P. J. Dyson, J. Med. Chem., 2005, 48, 4161-4171.

52 M. Schmidlehner, V. Pichler, A. Roller, M. A. Jakupec, W. Kandioller and B. K. Keppler, J. Organomet. Chem., 2015, 782, 69-76.

53 W. Kandioller, E. Balsano, S. M. Meier, U. Jungwirth, S. Göschl, A. Roller, M. A. Jakupec, W. Berger, B. K. Keppler and C. G. Hartinger, Chem. Commun., 2013, 49, 33483350 .

54 J. Ruiz, V. Rodríguez, N. Cutillas, K. G. Samper, M. Capdevila, Ò. Palacios and A. Espinosa, Dalton Trans., 2012, 41, 12847-12856.
55 O. Dömötör, S. Aicher, M. Schmidlehner, M. S. Novak, A. Roller, M. A. Jakupec, W. Kandioller, C. G. Hartinger, B. K. Keppler and É. A. Enyedy, J. Inorg. Biochem., 2014, 134, 57-65.

56 V. Novohradsky, L. Zerzankova, J. Stepankova, A. Kisova, H. Kostrhunova, Z. Liu, P. J. Sadler, J. Kasparkova and V. Brabec, Metallomics, 2014, 6, 1491-1501.

57 A. J. Millett, A. Habtemariam, I. Romero-Canelón, G. J. Clarkson and P. J. Sadler, Organometallics, 2015, 34, 2683-2694.

58 Z. Liu, I. Romero-Canelõn, B. Qamar, J. M. Hearn, A. Habtemariam, N. P. E. Barry, A. M. Pizarro, G. J. Clarkson and P. J. Sadler, Angew. Chem., Int. Ed., 2014, 53, 3941-3946.

59 J. M. Hearn, I. Romero-Canelón, B. Qamar, Z. Liu, I. Hands-Portman and P. J. Sadler, ACS Chem. Biol., 2013, 8, 1335-1343.

60 A. Casini, F. Edafe, M. Erlandsson, L. Gonsalvi, A. Ciancetta, N. Re, A. Ienco, L. Messori, M. Peruzzini and P. J. Dyson, Dalton Trans., 2010, 39, 5556-5563.

61 A. J. M. Duisenberg, L. M. J. Kroon-Batenburg and A. M. M. Schreurs, J. Appl. Crystallogr., 2003, 36, 220229.

62 R. H. Blessing, Acta Crystallogr., Sect. A: Fundam. Crystallogr., 1995, 51, 33-38.

63 G. M. Sheldrick, Acta Crystallogr., Sect. A: Fundam. Crystallogr., 2008, 64, 112-122.

64 K. Mikkelsen and S. O. Nielsen, J. Phys. Chem., 1960, 64, 632-637. 